\title{
A Four-stage Flipped Classroom Model for Seminar-based E-Commerce Learning
}

\author{
Huizhou Zhao 1, a * \\ ${ }^{1}$ College of Information Sciences, Beijing Language and Culture University, Beijing 100083, \\ China \\ azhaohuizhou@blcu.edu.cn \\ * corresponding author
}

\begin{abstract}
Keywords: Seminar-based Learning; Flipped Classroom; Four-stage Model; E-Commerce Course; Going on Learning Ability
\end{abstract}

\begin{abstract}
E-Commerce is a comprehensive, multidiscipline, rapidly developing area. The most import thing of learning organization researchers consider is to train the students' ability of going on learning by themselves. Researchers researchers carry out seminar-based learning organization in the the E-commerce course. This paper introduces the four-stage flipped classroom model by applying to the seminar-based learning. Comparing to the traditional teaching method, researchers concluded that the flipped classroommodel motivating the students' learning initiative well and the learning effect is mainly affected by the students' learning habits and the size of the class.
\end{abstract}

\section{Introduction}

E-Commerce is a course for the 3rd grade undergraduates at the College of Information Sciences in Beijing Language and Culture University. This course is a comprehensive and multidiscipline one, which relates to computer technology, network and communication technologies, business and management. Seminar-based learning [1-3] is a suitable organization way to this course, which includes many-sided contents, and many related areas are rapidly developing.

The most import thing of learning organization researchers consider is to train the students' ability of going on learning in the e-commerce area by themselves. In order to help the students to achieve good learning effect, researchers try to excite the students' initiative in the learning process.

The flipped classroom is a new pedagogical method, which needs the students to learn outside the classroom [4] and to participate in more interactive activities, such as problem solving, discussions and debates, in the classroom [5-7]. In the flipped classroom model, the potential value of student-centered learning environments is emphasized, in which students are actively engaged in higher-order tasks and taking charge of their own learning [8-10]. This pedagogical method can motivate the students' learning initiative.

In this paper, researchers introduce the four-stage flipped classroom model which is applying to the seminar-based learning in the E-commerce course.

\section{Seminar-based Learning Design}

The students are required to finish three tasks in the E-Commerce course: theme research which is for theory learning, comprehensive practice which is for students doing team-corporation practice in spare time, and final personal paper.Researchers Researchers apply seminar-based learning policy to the theme research task. 
Topics. The contents of E-Commerce course include three aspects: (1) the introduction to E-Commerce, (2) E-Commerce models and (3) E-Commerce supporting elements.Researchers Researchers provide 12 seminar topics (see Table 1), which cover all the contents of the course.

Table 1 Seminar Top ics

\begin{tabular}{|l|l|}
\hline Num. & Simple description of topics \\
\hline 1 & The definition and connotation of E-commerce. \\
\hline 2 & The E-commerce way of traditional enterprises. \\
\hline 3 & B2B. \\
\hline 4 & B2C. \\
\hline 5 & C2C. \\
\hline 6 & New model of E-commerce. \\
\hline 7 & Researchers bsite development and operational mainten ance. \\
\hline 8 & E-Commerce security. \\
\hline 9 & Fraud in E-commerce. \\
\hline 10 & E-cash and Internet payment. \\
\hline 11 & E-commerce logistics distribution and management. \\
\hline 12 & Mobile E-Commerce. \\
\hline
\end{tabular}

There are 60 students in the course and they are separated in 13 teams. After selecting a topic, a team should re-state the topic in the form of case-based analysis problem and that problem is the object for the team to do theme research. There are two teams selecting the same topic, but those two teams use different cases.

Procedure. The procedure of the seminar-based theme research for one topic includes the following activities: spare time research, in-classroom representation and discussion, submitting report. For every topic, except a report team, there is also a main question team which should prepare questions in advance for the in-classroom discussion.Researchers researchers apply four-stage flipped classroom model to this procedure, which will be introduced in detail in the next section.

Evaluation. The evaluation is emphasized on the procedure of learning. Seminar-based theme research is totally 47 scores in the 100-score learning procedure grading, which takes an $80 \%$ part of the course grading. The subsections of seminar-based learning grading are followed:

- Work in the report team (totally 30 scores). Including: information collection and usage advice ( 9 scores, personal score), out-classroom team seminar based on the seminar record ( 9 scores, personal score), in-classroom representation and question-answers (7 scores, team score), final research report ( 5 scores, team score).

- Work in the main question team (totally 10 scores, personal score). Based on the out-classroom preparation meeting record and the in-classroom performance.

- Performance in the in-classroom discussion when neither a member of the responsible report team nor a member of the main question team (totally 7 scores, personal score).

\section{Four-stage Flipped Classroom Model}

Researchers apply a four-stage flipped classroom model to every seminar-based learning: in-classroom self-learning guidance, out-classroom self-learning, in-classroom inter-learning and in-classroom feedback.

In-classroom Self-learning Guidance. In-classroom self-learning guidance means the teacher does self-learning guidance report one week before the in-classroom theme discussion. The guidance includes theme learning contents introduction, pointing out learning emphases, difficulties and attention matters of self-learning. The teacher also distributes discussion topic at the BLCU MOOC platform for self-learning discussion. 
Out-classroom Self-learning. Out-classroom self-learning means the students have one week to do out-classroom theme self-learning, including reading the text book, reviewing the self-learning guidance hand out, collecting materials from the network, sharing ideas and completing self-learning test at the BLCU MOOC platform. The students also participate in the discussion topics, which are distributed by the teacher, and set up new topics for discussion in the class if necessary.

For every theme, there is a report team and a main question team. Students in these two teams need to do especial preparation for the in-classroom presentation and discussion. After deciding the case-based problem for theme research, the report team needs to do more information collection, to do in-team discussion and to complete the demonstration materials for the in-classroom presentation. The main question team needs to do especial preparation for the in-classroom discussion. Students in this team need to track the procedure of the report team by viewing the sharing materials. The out-classroomface-to-face activities of the report team and the main question team are assisted by the teaching assistants.

In-classroom Inter-learning. In-classroom inter-learning includes the activities of presentation by the report team and discussion in the whole class. This stage includes the following activities: (1) theme research presentation, (2) real-time questions during the presentation, (3) real-time questions summary and answer, (4) discussion after presentation. Comparing to the traditional presentation and discussion model, the model encourages students express themselves in time during the presentation, and this can catch the flash points of the audiences.

In order to solve the wireless network instability problem, researchers set up dual channels for real-time discussion: web-based and WeChat-based. These two channels support well for the audiences expressing their ideas during the presentation.

In-classroom Feedback. In-classro om feedback means the teacher doing theme learning summary after the in-classroom discussion. Before the classroom time, the teacher prepares the initial summary handout based on the self-learning test result and the replies to the self-learning discussion topics. In the classroom, the teacher replenishes contents in to the summary based on the in-classroom presentation, questions and answers. After the class time, the final summary handout is published at BLCU MOOC platform.

\section{Learning Effects Analysis}

In the end of the semester, researchers carried out a survey among all the students for collecting the students' self-evaluation of learning effects. The self-evaluation aspects included course contents, theme research reports, learning materials and experiments. Based on these questionnaires and interview of the previous students, researchers compare the flipped-classroom based teaching method to the traditional teaching method (see Table 2). The previous E-Commerce course used the traditional teaching method, with which the in-classroom teaching is the main way during the course period.

Table 2 Comparison between Traditional and Flipped-classroom based Teaching $\mathrm{M}$ ethods

\begin{tabular}{|l|l|l|}
\hline Aspects & Traditional Teaching Method & Four-stage Flipped Classroom Model \\
\hline $\begin{array}{l}\text { Teaching } \\
\text { emphasis }\end{array}$ & Course contents. & $\begin{array}{l}\text { Policy and method to do team-based research } \\
\text { learning. The course contents are objects for } \\
\text { learning. }\end{array}$ \\
\hline $\begin{array}{l}\text { Teaching } \\
\text { organizatio } \\
\mathrm{n}\end{array}$ & $\begin{array}{l}\text { The teacher does in-classroom } \\
\text { teaching, and the students do spare } \\
\text { time learning if they want. }\end{array}$ & $\begin{array}{l}\text { The students are required to do series of } \\
\text { out-classroom tasks, including self-learning } \\
\text { each chapter contents, deeply researching a } \\
\text { theme. The teacher does in-classroom } \\
\text { guidance for students self-learning and } \\
\text { summary of theme learning. All the students }\end{array}$ \\
\hline
\end{tabular}




\begin{tabular}{|l|l|l|}
\hline & \multicolumn{1}{|c|}{$\begin{array}{l}\text { do inter-learning by presentation and } \\
\text { discussion on theme learning. }\end{array}$} \\
\hline $\begin{array}{l}\text { Classroom } \\
\text { organizatio } \\
\mathrm{n}\end{array}$ & $\begin{array}{l}\text { The teacher speaks and the } \\
\text { students listen in the classroom. } \\
\text { The Students are allowed to say } \\
\text { something if they want to or are } \\
\text { called by the teacher. }\end{array}$ & $\begin{array}{l}\text { More than half of the in-classroom time is for } \\
\text { the students presenting and discussing. Most } \\
\text { students participate in the discussion on their } \\
\text { will. The teacher controls the procedure of the } \\
\text { discussion, reminds the negative students to } \\
\text { pay attention to the discussion if necessary. }\end{array}$ \\
\hline $\begin{array}{l}\text { Teaching } \\
\text { preparation }\end{array}$ & Based on course contents. & $\begin{array}{l}\text { Based on course contents and the students } \\
\text { self-learning which includes test results and } \\
\text { online topic discussion. }\end{array}$ \\
\hline $\begin{array}{l}\text { Learning } \\
\text { gains }\end{array}$ & $\begin{array}{l}\text { The students get knowledge of } \\
\text { E-Commerce related knowledge. }\end{array}$ & $\begin{array}{l}\text { The students not only get knowledge of } \\
\text { E-Commerce related knowledge, but also } \\
\text { deeply understanding some topics such as the } \\
\text { responsible theme or favorite themes. The } \\
\text { students also get experience on real problem } \\
\text { solving through comprehensive practice. }\end{array}$ \\
\hline $\begin{array}{l}\text { Students } \\
\text { evaluation } \\
\text { on learning } \\
\text { Effect } \\
\text { each of } \\
\text { chapter }\end{array}$ & $\begin{array}{l}\text { Evaluations on different chapters } \\
\text { are almost the same. }\end{array}$ & $\begin{array}{l}\text { The students' subjective opinions show that } \\
\text { they get deep impression and good learning } \\
\text { effect on the responsible theme, but just know } \\
\text { the surface of other themes. The factors that } \\
\text { affect the learning effect of the whole class } \\
\text { include the in-classroom theme report quality } \\
\text { and the number of students who are } \\
\text { responsible for that theme research. }\end{array}$ \\
\hline $\begin{array}{l}\text { Students } \\
\text { ovaluation } \\
\text { burden. }\end{array}$ & $\begin{array}{l}\text { The students feel light } \\
\text { E-Commerce course. }\end{array}$ & $\begin{array}{l}\text { Students'feelings are different. Some students } \\
\text { think there are so many learning tasks in this } \\
\text { course, shoulder heavy learning burden, so } \\
\text { they want to be less required. Other students } \\
\text { who think themselves not active in course } \\
\text { study want to be more required. }\end{array}$ \\
\hline
\end{tabular}

\section{Summary}

According to the above comparison, researchers get the following conclusion: the four-stage flipped classroom teaching plan realized the target of motivating students' learning initiative. Researchers set up more learning tasks and detail requirements, and the students should finish the tasks step by step. This learning procedure directs the students both to get knowledge of the E-Commerce related knowledge and to deeply learn at least one topic in the E-Commerce area. The teaching target of encouraging the students practicing team-based research learning is well done.

On the other hand, the difference between students is obvious. This makes us to realize the limitations of the flipped classroom teaching method.

(1) The successful application of flipped classroom depends on the initiative of students. With this teaching method, the teacher guidance is mostly according to the students' performance in self-study and the questions raised by the students. Only the students, who take the initiative to learn and show the learning results, can obtain the valuable guidance from the teacher and learn more. 
(2) The effect of the flipped classroom teaching is greatly influenced by the number of students. There are 60 students in the course. Although researchers set up web-based and WeChat-based double channels for in-classroom discussion, only about 1/3 2/3 students take part in discussion in every class. There are always negative students who did not discuss in class. There also discussion opinions which cannot be replied in class. Researchers think a class with less than 30 students will enhance the overall learning effect by replying in time and correct the negative students' behavior effectively.

\section{Acknowledgement}

BLCU supported project for young researchers program (supported by "the Fundamental Research Funds for the Central Universities") (13YBG46, 12YBG01).

\section{References}

[1] X.H. Wang, Q.F. Luo and B. Hong, Application of Seminar-based Teaching in the Graduate Course of Id eological and Political Theories, Journal of Graduate Education 02 (2013) (In Chinese).

[2] H.Y. Lei, A Research on the Construction of Seminar-based Teaching Model in Undergraduate Teaching Practices, Journal of Nanyang Normal University, 07 (2010) (In Chinese).

[3] H.W. Chen, Application \& Investigation of the Seminar-based Teaching Methodology, Journal of Dongguan University of Technology, 01 (2010) (In Chinese).

[4] K. Fulton, Upside Down and Inside Out: Flip Your Classroom to Improve Student Learning, Learning \& Leading with Technology, 39(8) (2012) 12-17.

[5] S. Zappe, R. Leicht, J. Messner, T. Litzinger and H. Lee, "Flipping" the classroom to explore active learning in a large undergraduate course, Proceedings of the 2009 American Society for Engineering Education Annual Conference and Exhibition (2009).

[6] H. Hughes, Introduction to Flipping the College Classroom, In T. Amiel, \& B.Wilson (Eds.), Proceedings from World Conference on Educational Multimedia, Hypermedia and Telecommunications, (2012) 2434-2438.

[7] R.S. Davies, D.L. Dean and N. Ball, Flipping the Classroom and Instructional Technology Integration in a College-level Information Systems Spreadsheet Course, Educational Technology Research and Development, 61(4) (2013) 563-580.

[8] M. Hannafin, J. Hill and S. Land, Student-centered Learning and Interactive Multimedia: Status, Issues, and Implication, Contemporary Education, 68(2) (1997) 94-99.

[9] P. Shea, S. Hayes, S.U. Smith, J. Vickers, T. Bidjerano, A. Pickett, et al., Learning Presence: Additional Research on a New Conceptual Element within the Community of Inquiry (CoI) framework, The Internet and Higher Education, 15(2) (2012) 89-95.

[10] J.F. Strayer, How to Learn in an Inverted Classroom Influences Cooperation, Innovation and Task Orientation, Learning Environments Research, 15(2) (2012) 171-193. 